\title{
Reaction of rice cultivars to Meloidogyne graminicola as a function of irrigation management
}

\author{
Cristiano Bellé ${ }^{\star}$, Rodrigo Ferraz Ramos ${ }^{1}$, Ricardo Rubin Balardin ${ }^{1}$, Tiago Edu Kaspary ${ }^{2}$ and Andressa Lima \\ De Brida $^{3}$
}

${ }^{1}$ Federal University of Santa Maria, Santa Maria, RS, Brazil. ${ }^{2}$ Instituto Nacional de Investigación Agropecuaria, La Estanzuela, Uruguay. ${ }^{3}$ Federal University of Pelotas, Pelotas, RS, Brazil. *Author for correspondence: crbelle@gmail.com

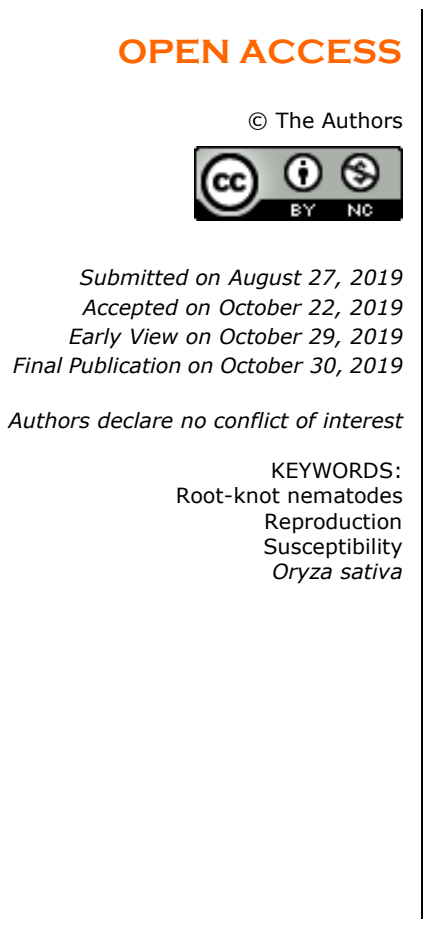

\section{ABSTRACT}

The objective of this study was to evaluate the reproduction of Meloidogyne graminicola in 22 cultivars of rice used in the southern region of Brazil according to the irrigation management. The design was completely randomized in a factorial scheme, being the factor A: rice cultivars and factor B: irrigation management (dry and flooded). The rice cultivars were kept individually in pot with sterilized substrate and inoculated with 5,000 eggs and juveniles (second stage - J2) of the nematode. Plants to rice cultivate BRS IRGA 410 was inoculated with $M$. graminicola and were used as controls. At 60 days after inoculation, the root system of each plant was evaluated number of galls (NG), number of nematodes per gram root (NNGR) and the reproduction factor (RF). The results demonstrate that $M$. graminicola can parasitize and develop in different rice cultivars that are commonly used in commercial crops in the Southern region of Brazil, and all cultivars evaluated were classified as susceptible to this nematode $(F R>1.00)$. The cultivation system under flood conditions showed significantly lower values for the NG, NNGR and RF.

\section{Highlighted Conclusions}

1. The cultivars BRS Firmeza, IRGA 421, IRGA 423, IRGA 424, IRGA 436, IRGA 428 CL, IRGA 429, Inov CL, Avaxi CL, BRS Catiana and SCS121 CL showed the lowest RF in the flooded crop.

2. The use of cultivars with lower nematode RF in early flood cropping systems is a strategy indicated to reduce the population and the potential for damage caused by M. graminicola in areas with rice crop.

\section{INTRODUCTION}

Rice (Oryza sativa L.) is the most cultivated and consumed crop worldwide, being the basic food for about 3.5 billion people, consisting in a strategic crop both economically and socially (Fidelis et al. 2012, Muthayya et al. 2014). In the world, estimatives indicate that approximately 480 million tons of benefited rice are produced annually (Muthayy et al. 2014). Brazil cultivates an area of approximately 1.97 million hectares of irrigated rice, with production of 12.03 million tons of grains, and annual domestic consumption of 12 million tons (CONAB 2018). The Rio Grande do Sul state, where the irrigated cultivation system predominates, is the main Brazilian producer, accounting for $68.9 \%$ of the national rice production (Brasil 2018 ).

The rice crop may have negative interference of different biotic and abiotic stresses throughout its development cycle. Among the biological factors that affect the development and productivity of rice is the negative effect caused by competition with weeds, diseases and pests. Therefore, one of the main pests that occurs in the crop is the rootknot nematode (Meloidogyne graminicola Golden and Birchfield) that can cause a great decrease in the productive potential of the rice (Golden and Birchfield 1965). The productivity losses caused by this plant-parasitic nematode can vary from 11 to $90 \%$, depending on the different sensitivity levels of the rice cultivars (Soriano and Reversat 2003, Padgham et al. 2004, De Waele and Elsen 2007, Kyndt et al al. 2014).

The occurrence of $M$. graminicola species was initially reported by parasitizing Echinochloa colonum (L.) roots and later found in rice, both in the United States (Golden and Birchfield 1965, 1968). There are currently reports 
that this plant-parasitic nematode can parasitize more than 100 plant species, including grasses and dicotyledons (Naalden et al. 2018). In this way, it is widely distributed in almost all producing countries, parasitizing rice crops in flooded systems and dry systems (Dutta et al. 2012, Jain et al. 2012). In Brazil, M. graminicola has been detected since the 1990s, parasitizing rice plants and rice grass (Echinochloa sp.) in fields from Rio Grande do Sul State (Sperandio and Monteiro 1991, Gomes et al. 1997). It has recently been reported that M. graminicola is the predominant plant-parasitic nematode species in the main rice-growing areas of the country (Negretti et al. 2017).

The management of Meloidogyne spp. requires different tools, as use of resistant genotypes and the implementation of crop rotations with non-host species (Mattos et al. 2017). However, options tomanage $M$. graminicola are still limited, because of the few resistant rice genotypes (Dutta et al. 2012, Phan et al. 2018).

Studies report lower yield losses of rice cultivation caused by $M$. graminicola, when the crop was submitted to early flooding and the water maintained until the end of its crop cycle, this can be a tool for the management of this plant-parasitic nematode (Soriano et al. 2000, De Waele and Elsen 2007). Thus, the selection of susceptible cultivars to M. graminicola and the effect of the water depth on the development of this nematode can contribute to obtain resistant genotypes to be used in management programs and to indicate management strategies of this important parasite of rice cultivation. In this context, the objective of this work was to evaluate the reproduction of M. graminicola in rice cultivars used in the southern region of Brazil due in the absence or presence of irrigation by submersion.

\section{MATERIAL AND METHODS}

The experiment was conducted from agricultural crop year 2018 to assess the reaction of 22 different rice cultivars (Avaxi CL, BRS Atalanta, BRS Catiana, BRS Firmeza, BRS Pampa, BRS Pampeira, BRS Querência, BRS Sinuelo CL, Guri Inta CL, Inov CL, BR IRGA 410, IRGA 417, IRGA 421, IRGA 423, IRGA 424, IRGA 426, IRGA $428 \mathrm{CL}$, IRGA 429, Puitá Inta CL, SCS117 CL, SCS121 CL, and Titan CL) to M. graminicola under greenhouse conditions with temperatures ranging from 22.5 to 27.5. Experiments were conducted in a completely randomized experimental design, in factorial scheme, where factor A corresponded to the rice cultivars and factor $B$ to irrigation (dry and flooded), with ten replications. Rice cultivar BR-IRGA 410 was used as controls for nematode inoculum viability.

The inoculum used was a pure population of M. graminicola, collected in weeds of rice-fields (Bellé et al. 2019), kept under greenhouse rice plants cv. BR IRGA 410. The soil used in the experiment is classified as Planossolo Hidromórfico Eutrófico Arênico, according to the Brazilian Soil Classification System (Embrapa 2013), with the following characteristics: clay $=48 \%$; water $\mathrm{pH}$ value $=5.9$; SMP index $=6.3$; organic matter $=3.8 \%$; phosphorus $=$ $12.2 \mathrm{mg} \mathrm{dm}^{-3} ;$ potassium $=68 \mathrm{mg} \mathrm{dm}{ }^{-3} ;$ calcium $=6.8 \mathrm{cmol}_{\mathrm{c}} \cdot \mathrm{dm}^{-3} ;$ magnesium $=2.7 \mathrm{cmol}_{\mathrm{c}} . \mathrm{dm}^{-3} ;$ and sulfur $=3.4$ cmolc. $\mathrm{dm}^{-3}$.

Five days after emergence, seedlings were transplanted to four-liter pots containing sterilized soil, one plant per pot. Plants were inoculated five days after transplanting with a suspension of 5,000 eggs and second-stage juvenile (J2) specimens into three holes of approximately two centimeters in depth, made around the plant base. In the dry condition, plants were irrigated when necessary. In the flooded condition, after 5 days of inoculation, a water depth of $2.0 \mathrm{~cm}$ above the soil surface of each pot was maintained until the end of the experiment.

Sixty days after inoculation, root system was washed individually under tap water, weighted after removing the excess of water with paper towels and counting of the number of galls. The number of galls/root system was assessed and after counting the number of galls, the root systems were processed following the method of Hussey and Barker (1973), using a $0.5 \%$ sodium hypochlorite solution to triturate the roots in a blender to obtain the final suspension for nematode population quantification. This number was used to obtain the reproduction factor $(\mathrm{RF}=$ final population (Pf)/initial population (Pi)), as methodology proposed by Oostenbrink (1966), where the rice cultivars were classified as RF $<1.00$ for resistant and RF $>1.00$ for susceptible. In addition, the number of nematodes per gram of root was estimated, which is defined by the ratio between the total number of nematodes and the total mass of the roots in grams of each replicate. Data obtained were analyzed for normality by the Shapiro-Wilk test, to homoscedasticity by the Hartley test and subsequently analyzed of variance, and the treatments means were compared by the Scott-Knott at a significance level of $5 \%$. The effects of irrigation management were analyzed by the $t$ test $(p \leq 0.05)$ using the Genes software (Cruz 2006).

\section{RESULTS AND DISCUSSION}

The different rice cultivars, as well as the different irrigation management, showed a significant interaction on the parasitism capacity of the root-knot nematode, M. graminicola (Table 1). For all cultivars evaluated, the flooded 
system allowed significantly higher values for the number of galls (NG), nematode per gram of roots (NNGR) and reproduction factor (RF) of the root-knot nematode (Table 1).

Table 1. Number of galls (NG), number of nematodes per gram of root (NNGR) and reproduction factor (FR) of Meloidogyne graminicola in rice roots kept under dry and flooded conditions.

\begin{tabular}{|c|c|c|c|c|c|c|c|c|c|c|}
\hline \multirow{3}{*}{$\begin{array}{l}\text { Cultivars } \\
\text { Avaxi CL }\end{array}$} & \multicolumn{2}{|c|}{ NG } & \multicolumn{4}{|c|}{ NNGR $^{1}$} & \multicolumn{4}{|c|}{$\mathbf{R F}^{2}$} \\
\hline & Dry & Flooded & \multicolumn{2}{|l|}{ Dry } & \multicolumn{2}{|c|}{ Flooded } & \multicolumn{2}{|c|}{ Dry } & \multicolumn{2}{|c|}{ Flooded } \\
\hline & $346 c^{3 *}$ & $250 \mathrm{c}$ & 1676 & $c^{*}$ & 1031 & $\mathrm{C}$ & 20.8 & $c^{*}$ & 11.1 & $\mathrm{c}$ \\
\hline $\mathrm{BR}$ IRGA $410^{\top}$ & $950 \mathrm{a}^{*}$ & 576 a & 5690 & $a^{*}$ & 2939 & $\mathrm{a}$ & 57.2 & $a^{*}$ & 25.6 & a \\
\hline BRS Atalanta & $496 c^{*}$ & $331 b$ & 2256 & $c^{*}$ & 1278 & $c$ & 29.8 & $c^{*}$ & 14.7 & $b$ \\
\hline BRS Catiana & $402 c^{*}$ & $280 \mathrm{c}$ & 1867 & $c^{*}$ & 1108 & $c$ & 24.1 & $c^{*}$ & 12.4 & $\mathrm{c}$ \\
\hline BRS Firmeza & $379 c^{*}$ & $214 d$ & 1336 & $d^{*}$ & 871 & $\mathrm{~d}$ & 16.8 & $d^{*}$ & 9.5 & c \\
\hline BRS Pampa & $608 b$ * & 392 b & 2759 & $C^{*}$ & 1513 & $\mathrm{~b}$ & 36.5 & $b^{*}$ & 17.4 & $b$ \\
\hline BRS Pampeira & $700 \quad b$ * & $441 \mathrm{~b}$ & 4265 & $b^{*}$ & 2289 & $\mathrm{~b}$ & 42.0 & $b^{*}$ & 19.6 & $b$ \\
\hline BRS Querência & $658 b^{*}$ & $419 b$ & 3327 & $b^{*}$ & 1802 & $\mathrm{~b}$ & 39.5 & $b^{*}$ & 18.6 & $b$ \\
\hline BRS Sinuelo CL & $696 b^{*}$ & $439 \mathrm{~b}$ & 3251 & $b^{*}$ & 1746 & $\mathrm{~b}$ & 41.8 & $b^{*}$ & 19.5 & $b$ \\
\hline Guri Inta CL & $454 c^{*}$ & $308 c$ & 2250 & $c^{*}$ & 1301 & $c$ & 27.3 & $c^{*}$ & 13.7 & $b$ \\
\hline Inov CL & $421 c^{*}$ & $290 \mathrm{C}$ & 2085 & $C^{*}$ & 1225 & $\mathrm{C}$ & 25.3 & $c^{*}$ & 12.9 & c \\
\hline IRGA 417 & $298 d$ * & $191 d$ & 1403 & $d^{*}$ & 963 & $\mathrm{~d}$ & 14.3 & $d^{*}$ & 8.5 & c \\
\hline IRGA 421 & $290 d^{*}$ & $171 \mathrm{~d}$ & 964 & $e^{*}$ & 702 & $\mathrm{~d}$ & 12.0 & $d^{*}$ & 7.6 & $\mathrm{c}$ \\
\hline IRGA 423 & $258 d^{*}$ & $126 \mathrm{~d}$ & 1282 & $d^{*}$ & 532 & $\mathrm{~d}$ & 15.5 & $d^{*}$ & 5.6 & $\mathrm{c}$ \\
\hline IRGA 424 & $254 d^{*}$ & $150 \mathrm{~d}$ & 1261 & $d^{*}$ & 846 & $\mathrm{~d}$ & 15.3 & $d^{*}$ & 8.9 & c \\
\hline IRGA 426 & $396 c^{*}$ & $277 \quad c$ & 1948 & $c^{*}$ & 1160 & $c$ & 23.8 & $c^{*}$ & 12.3 & c \\
\hline IRGA $428 \mathrm{CL}$ & $267 d^{*}$ & $145 \mathrm{~d}$ & 1375 & $d^{*}$ & 909 & $d$ & 16.5 & $d^{*}$ & 9.2 & $c$ \\
\hline IRGA 429 & $263 d^{*}$ & $153 \mathrm{~d}$ & 1293 & $d^{*}$ & 640 & $\mathrm{~d}$ & 15.8 & $d^{*}$ & 6.8 & c \\
\hline PUITÁ INTA CL & $479 c^{*}$ & 322 b & 2260 & $c^{*}$ & 1293 & $\mathrm{C}$ & 28.8 & $c^{*}$ & 14.3 & $b$ \\
\hline SCS117 CL & $575 b$ * & $374 \quad b$ & 2924 & $b^{*}$ & 1618 & $\mathrm{~b}$ & 34.5 & $b^{*}$ & 16.6 & $b$ \\
\hline SCS121 CL & $413 c^{*}$ & $286 \mathrm{C}$ & 2131 & $c^{*}$ & 1257 & $\mathrm{C}$ & 24.8 & $c^{*}$ & 12.7 & c \\
\hline Titan CL & $542 b$ * & $356 \mathrm{~b}$ & 2757 & $c^{*}$ & 1541 & $\mathrm{~b}$ & 32.5 & $c^{*}$ & 15.8 & $b$ \\
\hline Average & 450 & 300 & 2289 & & 1298 & & 27.0 & & 13.3 & \\
\hline CV (\%) & \multicolumn{2}{|c|}{16.75} & \multicolumn{4}{|c|}{18.95} & \multicolumn{4}{|c|}{21.5} \\
\hline
\end{tabular}

The control cultivar BR IRGA 410 showed the lowest values for the NG, NNGR and RF variables in both water management systems, when compared to the other cultivars (Table 1). In the dry system, this cultivar average values of 950,5690 and 57.2 for the variables NG, NNGR and RF, respectively. However, the same cultivar in the flooded system showed significantly lower mean values with a reduction of $39.4 ; 48.3$ and $55.2 \%$ for NG, NNGR and RF, respectively. Therefore, flooding significantly reduces the parasitism and multiplication capacity of $M$. graminicola.

The cultivars IRGA 417, IRGA 421, IRGA 423, IRGA 424, IRGA 428 CL and IRGA 429 showed the lowest values for the number of galls per roots for both irrigation systems (Table 1). While the cultivar BRS Firmeza showed intermediate results for NG in the dry system, but for the flooded condition lower values and, in conjunction with the cultivars mentioned above, obtained the lowest performance for NG. For the variable nematode number per root number of nematodes per gram of roots, the cultivar IRGA 421 obtained the lowest value in the rainfed system, with 964 individuals (NNGR). The cultivars IRGA 423, IRGA 429, IRGA 421, IRGA 424, BRS Firmeza, IRGA $428 \mathrm{CL}$ and IRGA 417 showed the lowest values of NNGR, with 532, 640, 702, 846, 871, 909 and 963 individuals, respectively.

All the 22 rice cultivars evaluated showed a reproduction factor higher than 1.00 , irrespective of the irrigation management, and were considered susceptible to M. graminicola according to the classification proposed by Oostenbrink (1966). However, it was observed that all rice cultivars submitted to the flood-irrigated system lower values for the reproductive factor when compared to the dry system (Table 1). It was observed that the cultivars BRS Firmeza, IRGA 417, IRGA 421, IRGA 423, IRGA 424, IRGA 436, IRGA 428 CL and IRGA 429 presented the 
smallest reproduction factors for both irrigation systems, whereas in the flooded crop, the cultivars Inov CL, Avaxi $\mathrm{CL}$, BRS Catiana and SCS121 CL also resulted in the lowest values of RF along with the cultivars mentioned above.

The damages caused by $M$. graminicola in the rice crop is related to the survival capacity and complete development of the plants, occurring for crops grown in dry or flooded systems. The results of the present study show that this plant-parasitic nematode is adapted to different environments, can survive under flood conditions, and thus may cause damage in different rice agroecosystem. The survival and damage caused by M. graminicola in distinct environments is also reported by other studies which also connect their infestation from egg deposition on the roots performed by adult individuals or from the migration of juvenile from the soil generating the formation of new galls (Dutta et al. 2012, Kyndt et al. 2014, Mantelin et al. 2017).

The classical infestation of $M$. graminicola leads to the formation of root galls (popularly known as "umbrella cables") at the tip of young roots (Gomes et al. 1997). These galls in the rice crop cause the alteration of the vascular system, causing disruption of water and nutrient transportation, stunting, chlorosis, loss of vigor, reduction of the number of tillers, poor growth and reproduction of the plants, resulting in significant losses (Bernard et al. 2017, Mantelin et al. 2017). The average losses in rice cultivation due to this nematode species vary between $17 \%$ and $32 \%$ and can reach up to $90 \%$ in yield reduction in cases of high infestations (Padgham et al. 2004, Kyndt et al. 2014).

The reduction of infestation and reproduction of $M$. graminicola was evidenced in the present study for the condition of soil flooding, indicating a greater tolerance by the crop and reduction of plant-parasitic nematode adaptability to a condition of lower oxygen. The present study corroborates with the results reported in studies where the sowing of the cultivars Thihtatyin and Yatanarto in an environment with presence of water lamina or submitted to early irrigation, reduced the infestation and the damages caused by $M$. gramicola in comparison with the sowing in dry soil or with late irrigation (Win et al. 2016). In this sense, the onset of flooding immediately after sowing or sowing in pre-germinated systems may limit the infestation capacity of the roots by the nematode (Soriano et al. 2000, Gilces et al. 2016). Thus, reducing the presence of the nematode can reduce yield losses whit the use of precocious flooding or before sowing of the crop, becoming a tool of management of this phytoparasite.

The results obtained demonstrate that the $M$. graminicola can parasitize, develop and reproduce in different rice cultivars that are commonly used in commercial crops in the southern Brazil. They also show that this phytoparasite can develop in rice plants cultivated under dry and flooded system, however, presenting a lower number of galls, nematode per gram of root and reproduction factor in the flooding. Thus, it is necessary to adopt integrated practices for the efficient management of this important nematode species of rice crop, with the adoption of less sensitive cultivars, flooding of the area and rotation of crops with resistant species. In this way, the population of this plant-parasitic nematodes can be reduced in cultivated areas and minimized the losses caused by $M$. graminicola in rice crop.

\section{References}

Bernard GC et al. 2017. The impact of plant-parasitic nematodes on agriculture and methods of control. IntechOpen e68958:121-151.

Bellé C et al. 2019. Detection of Meloidogyne graminicola parasitising Cyperus rotundus in Rio Grande do Sul, Brazil. Australasian Plant Disease Notes 14:2

Brasil. 2018. Ministério da Agricultura, Pecuária e Abastecimento. Projeções do Agronegócio: Brasil 2017/18 a 2027/28 projeções de longo prazo. Brasília: MAPA/ACE, $112 \mathrm{p}$.

CONAB - Companhia Nacional de Abastecimento. 2018. Perspectivas para a agropecuária - Safra 2018/2019. Brasília: CONAB. 104p.

Cruz CD. 2006. Programa Genes - Estatística Experimental e Matrizes. Editora UFV: Viçosa

De Waele D and Elsen A. 2007. Challenges in tropical plant nematology. Annual Review of Phytopathology 45:457-485.

Dutta TK et al. 2012. Global status of rice root-knot nematode, Meloidogyne graminicola. African Journal of Microbiology Research 6:60166021.

Fidelis RR et al. 2012. Eficiência do uso de nitrogênio em genótipos de arroz de terras altas. Pesquisa Agropecuária Tropical 42:124-128.

Gilces CT et al. 2016. Plant-parasitic nematodes associated with rice in Ecuador. Nematropica 46:45-53

Golden AM and Birchfield W. 1965. Meloidogyne graminicola (Heteroderidae), a new species of root-knot nematode from grass. Proceedings of the Helminthological Society of Washington 32:228-231.

Golden AM and Birchfield W. 1968. Rice root-knot nematode Meloidogyne graminicola as a new pest of rice. Plant Disease Reporter 52:423.

Gomes CB et al. 1997. Ocorrência Meloidogyne graminicola em Santa Maria, RS. Ciência Rural 27:501-502.

Hussey RS and Barker KR .1973. A comparison of methods of collecting inocula of Meloidogyne spp., including a new technique. Plant Disease Report 57:1025-1028

Jain RK et al. 2012. Rice root-knot nematode (Meloidogyne graminicola) infestation in rice. Archives of Phytopathology and Plant Protection 45:635-645.

Kyndt T et al. 2014. Plant-parasitic nematode infections in rice: molecular and cellular insights. Annual Reviews of Phytopathology 52:135-153.

Mantelin S et al. 2017. Meloidogyne graminicola: a major threat to rice agriculture. Molecular Plant Pathology18:1-15.

Mattos VS et al. 2017. Caracterização de um complexo de espécies do nematoide das galhas parasitando arroz irrigado na Região Sul do Brasil. Boletim de Pesquisa e Desenvolvimento 33:1-28. 
Muthayya S et al. 2014. An overview of global rice production, supply, trade, and consumption. Annals of the New York Academy of Sciences 1324:7-14

Naalden D et al. 2018. The Meloidogyne graminicola effector Mg16820 is secreted in the apoplast and cytoplasm to suppress plant host defense responses. Molecular Plant Pathology 19:2416-2430.

Negretti RR et al. 2017. Characterisation of a Meloidogyne species complex parasitising rice in southern Brazil. Nematology 19:403-412. Oostenbrink M. 1966. Major characteristic of relation between nematodes and plants. Mededelingen Landbouwhogeschool 66?1-46.

Phan NT et al. 2018. A Hypersensitivity-Like Response to Meloidogyne graminicola in Rice (Oryza sativa). Phytopathology 108:521-528.

Padgham JL et al. 2004. Impact of wheat on Meloidogyne graminicola populations in the rice-wheat system of Bangladesh. Nematropica 34:183-190

Embrapa - Empresa Brasileira de Pesquisa Agropecuária. 2013. Sistema Brasileira de Classificação de Solos. 3ª ed. Brasília: Embrapa. 353p.

Soriano IR et al. 2000. Expression of tolerance for Meloidogyne graminicola in rice cultivars as affected by soil type and flooding. Journal of Nematology 32:309-317

Soriano IR and Reversat G. 2003. Management of Meloidogyne graminicola and yield of upland rice in South-Luzon, Philippines. Nematology 5:879-884.

Sperandio CA and Monteiro AR. 1991. Ocorrência de Meloidogyne graminicola em arroz irrigado no Rio Grande do Sul. Nematologia Brasileira 15:24.

Win PP et al. 2016. Effect of planting and irrigation practices on nematode reproduction, root galling, plant growth and yield of two Asian lowland rice varieties infected by the rice root-knot nematode Meloidogyne graminicola. Russian Journal of Nematology 24:33-48. 